\title{
Transformations of spatial relationships in elementary education: A case study of changes in two Czech rural areas since the second half of the $20^{\text {th }}$ century
}

\author{
Silvie R. KUČEROVÁa , Jan D. BLÁHAa ${ }^{a}$ Zdeněk KUČERA ${ }^{a}$
}

\begin{abstract}
Transformations in the spatial organization of elementary education in the Czech Republic over the last 50 years are examined in this article, via case studies of two rural regions (Turnov district and Zábřeh district). The aim of the study is to investigate the impact of general development trends in elementary schools in territorial detail. Changes in the spatial distribution of schools, the size of school catchment areas, and the main education-related commuter flows are analyzed and visualized in cartographic form, in the context of educational policy and management.
\end{abstract}

Keywords: elementary education; educational policy; school patterns; catchment areas; rural areas; Turnov district; Zábřeh district; the Czech Republic

\section{Introduction}

With the evolution and expansion of transportation options during the $20^{\text {th }}$ century, demographic changes and the depopulation of peripheral rural areas, there were pressures on restricting the "costly luxury" of the smallest villages having their own school. Many experts and scientists were already dealing with this issue in the 1980s. For example, Tricker and Mills (1987, p. 37) accurately summarized the fact that "educational provision in rural areas has been progressively withdrawn from the smallest settlements and concentrated in larger centres further up the urban hierarchy." This necessarily led to the transformation of access to elementary education and of spatial relationships between communities and schools, municipalities and schools, as well as mutually between educational institutions. In the Czech Republic, several general trends related to this process have been repeatedly identified, e.g. by Hampl, Gardavský, Kühnl (1987), Hampl (2004), etc. The social consequences of school closures, which had the strongest impacts on rural areas, are also well known and were discussed by Bell and Sigsworth, 1987; Nitta, Holley, Wrobel, 2010; Witten, McCreanor, Kearns, Ramasubramanian, 2001, etc.

Nevertheless, the spatial organization of the elementary education system is still undergoing transformation in most developed countries. According to recent research, in many countries this transformation process is still continuing and becoming stronger, as its qualitative characteristics develop (e.g. Ĺberg-Bengtsson, 2009; Kearns, Lewis, McCreanor, Witten, 2009). The provision of elementary education is a relatively important political issue, which, in the context of overall state governance and economic development, changes over time. The provision of elementary education in rural areas is now often debated in the context of the sustainable development of rural areas, or identities of rural communities in the context of broadly understood spatial policy, planning and management (Kvalsund, 2009; Ribchester, Edwards, 1999; Walker and Clark, 2010).
Most scholarly studies of this issue refer to quantitative data to document the transformation of school patterns and the process of school closures. Some refer to the number of closed schools (Ĺberg-Bengtsson, 2009) over a short period of time and to local study areas. Other studies focusing on similar time intervals and locations provide a basic comparison of the number of schools at various points in time (Dowling, 2009). Sometimes they are supplemented with an illustration of trends by means of graphs (Kalaoja and Pietarinen, 2009) or, in exceptional cases, by maps (Basu, 2007). The overall scope of these changes at a macroregional scale, however, is usually not presented (but see Bell and Sigsworth, 1987 for an exception). These are factors that are assumed rather than actually documented by long-term statistics. What do the "dramatic wave of school closures" and the "closure of hundreds of them [schools]", as described by Karlberg-Granlund (2009), mean in the context of changes in larger territorial units, for example, in an entire country?

In our previous studies, we attempted to use the case of the Czech Republic to provide an analysis of school pattern changes on a macro-regional scale for the whole country, approximately in the last 50 years (Kučerová, 2012; Kučerová and Kučera, 2012; Kučerová, Mattern, Štych, Kučera, 2011). Thus, the main trends in school pattern changes have already been documented. Nonetheless, the detailed territorial impact of these changes still has to be presented adequately. This is particularly true for those rural peripheral areas that have been affected most by the school closures. The goal of this article is to use examples at the micro-regional level to demonstrate how the territorial organization of elementary education, as well as the related spatial relationships in access to education in the Czech countryside, changed in the above-mentioned period.

We aim to answer the following questions: What percentage of elementary schools in our model areas have been closed since the mid- $20^{\text {th }}$ century? What extensive changes have occurred in the delimitation of the catchment regions of

\footnotetext{
${ }^{a}$ Department of Geography, Jan Evangelista Purkyně University in Ústí nad Labem, Faculty of Science, Ústí nad Labem, Czech Republic; (corresponding author: S. R. Kučerová, e-mail: silvie.kucerova@ujep.cz)
} 
individual schools? How have commuter flows changed in specific areas? The findings will be visualized in cartographic form and discussed in the context of overall changes in the Czech Republic as a whole. With the help of these analyses, we aim to acquire a relevant base for a further study of how the provision of education works in the countryside and what are the relationships between actors in elementary education. Far from just involving changes in the temporal and spatial organization of commuting, we presume this transformation was part of a much larger reorganization of territorial, institutional, and social relationships.

The structure of this study, one small part of a larger whole, corresponds with each of our research goals. Within the general framework of providing education, we will first turn our attention to several concepts in educational policy in relation to education at a regional and local level. It is educational policy which creates the legislative, organizational and financial framework for the spatial organization of the educational system. Then, we shift our focus to the methodology of data collection and cartographic visualization of school patterns and commuter flows in the case study areas. The second part of the paper presents an interpretation and generalization of the results.

\section{Policy of providing elementary education}

\subsection{Providing elementary education}

The state is responsible for establishing a system of elementary education in its territory, which is centrally guaranteed to ensure a qualified labor force for the national economy and to maintain a society with certain knowledge, skills, and attitudes valued at the given time and by the given culture (Brown, Halsey, Lauder, Wells, 1997). Therefore, it is in the interest of the state that this service is provided uniformly throughout its entire territory at the same level of quality. All students should have an equal access to it regardless of gender, ethnicity, faith, social standing, health status, etc. (see, for example, the Czech School Act No. 561/2004 Coll., or similar legislation in other countries). What do we understand by 'equal access' in physical terms - of distance and other geographical characteristics?

Since the idea of compulsory education became established in the majority of European countries, networks of stateguaranteed schools were slowly built. They more-or-less equally covered the entire territory of the countries. In addition to this public school network, a less thoroughly planned network of educational institutes exists, including those organized by churches and various forms of higher education (Váňová, 2007). General spatial patterns of the organization of activities, as described by Hampl (1998) or Maryáš (1983), for example, tended to be reported with the school network expanding and growing denser. Even noncommercial services can be provided only if certain conditions are met; therefore, some services could be provided only in certain locations (population centres). The inequality in the territorial distribution of services at a micro-regional scale is therefore relatively high. Every educational institution has a defined service provision region. The higher and more specialized the form of education involved, the greater its territorial concentration.

In the school system, therefore, a hierarchy that corresponds with the hierarchy of the significance and size of population centres, can be observed. A similar - yet less progressive - hierarchy can be observed in the elementary school system itself. In most countries with developed educational systems, elementary education is broken down into two levels of education. These two levels may be combined into one institution. On the one hand, there are full elementary schools (hereinafter FES) with all grades of compulsory education. On the other hand, an elementary school can be incomplete (hereinafter IES), which is more common in rural areas with smaller populations of schoolaged children. Such schools offer only primary education or perhaps even just several years of primary education. Then pupils must commute to larger schools situated in local centres in order to complete their lower secondary education. This higher level of compulsory schooling is territorially concentrated, as it is provided in a lower number of settlements.

The discussion in many educationally-developed countries is about the position and function of IESs in the school system (White and Corbett, [eds.], 2014). Are IESs fullyfledged components of the educational system, or are they just unequal and inferior partners to FESs? Should IESs be subject to and serve the needs of FESs, or do they have the right to set their own educational goals and function as independent units (Dvořák, Starý, Urbánek, Chvál, Walterová, 2010)? Although most researchers working on small rural schools are in agreement that IESs are culturallyspecific educational entities (e.g. Bell and Sigsworth, 1987; Kalaoja and Pietarinen, 2009; Karlberg-Granlund, 2009; Walker and Clark, 2010), IESs are, particularly in educational policy, perceived as lower-level versions of larger urban schools (Kvalsund, 2009). FESs thus serve as the models of "school normality", and various criteria indicating performance, organization, facilities, etc., are presented in relation to and in comparison with FESs. IESs cannot meet the standards expected of urban schools. Therefore, they are necessarily imperfect and perceived as providing lower quality education (Bell and Sigsworth, 1987). This unequal relationship is then projected in school choice preferences and in the characteristics of catchment areas.

\subsection{Policy in the management of catchment areas}

Since elementary education is compulsory, its accessibility is ensured by legislation establishing the maximum distance both physical distance and travel time - at which an elementary school could be for pupils who attend it. These limits are usually contained in most school-related legislations.

It was necessary to bring schools as close as possible to their "customers" - to fill the schools without pupils having to overcome transportation difficulties to get there. Thus, pupils were assigned to schools generally according to the school's catchment area, which included the surrounding built-up area, the village, and the nearby isolated homes. Therefore, the elementary school network used to be characterized as being very dense, with at least an IES even in small settlements. As transportation became more effective and less expensive in the $20^{\text {th }}$ century, however, it became easier for pupils to get to schools that were farther away. The ratio between the material inputs per pupil for education at a local school versus transportation elsewhere, changed. Schools with too few pupils quickly found themselves in a very disadvantaged position due to this situation. Moreover, they were often located in buildings in poor technical shape that were difficult to maintain, in small peripheral villages.

One of the priorities of centralized educational policy in most countries is to ensure the quality of elementary education, while maintaining as much financial effectiveness 
as possible (Kvalsund, 2009). This, measured by short-term profits, means a guarantee of maximum output (i.e. educated pupils) with minimum input. When these criteria are applied, IESs are clearly less advantaged. If technical and financial means allow for appropriate transportation opportunities, it is more effective for pupils to be concentrated in a smaller number of educational institutes and to ensure their transportation to these centres.

The growing interrelations between individual locations in space created by transportation have resulted in educational policy facing a dilemma in the management of providing education in all regions. Regions that were originally comprised of small catchment areas that were more or less homogeneous are increasing significantly in size and are becoming more heterogeneous. When families consider where to send their children to school, many factors come into play: the nature of the parents' journeyto-work, existing regularly-scheduled public transportation connections, the existence of two schools of different quality at the same distance, etc. (e.g. Walker and Clark, 2010). Due to the limited capacity of particular educational institutes or attempts to distribute public services evenly, most countries originally adopted a policy of delimiting clear catchment areas for each individual settlement unit including a school.

Spatial calculations based on gravitational models were used very often (Marsden, 1977). This directed provision of education does bring schools short-term client stability and greater ease of forecasting market developments in specific areas (e.g. by calculating changes in the number of pupils through population forecasts). In situations where the number of pupils declines or where the age structure of pupils is irregular, however, schools are at a great risk of closure without being able to attract other clients. This only strengthens competitive relationships that lack transparency (e.g. schools "fighting for" pupils). In such educational policies, the unit of interest is not the school (as a single institution). Rather, a school pattern is considered to be an equalitarian unit: a tool for education, in which every school is ideally replaceable by another, if reorganized. This kind of policy does not take into account the specifics of each educational institute nor the local relationships between schools and local communities (Kvalsund, 2009).

Since the 1980s, as a result of population change pressures (declining numbers of pupils), liberalization policies, and attempts at cutting costs while increasing effectiveness in the public sector, many countries have begun to openly support a (quasi-) market environment in the school system (Bradford, 1991; Nekorjak, Souralová, Vomastková, 2011). Strictly defined catchment areas for elementary schools have been abandoned, and parents have been given the possibility to choose which school to send their children to. This type of educational policy openly declares competition between schools, legalizes such competition, and supports a heterogeneous school pattern. It also helps, however, to widen the rapidly increasing gap between "successful" and "unsuccessful" schools - based on generally measurable criteria, such as better test results in statewide tests, contests, etc. The unit of interest has become the individual school, as each school receives generally different funds based on its results (Bradford, 1991; Bajerski, 2011). This once again boosts differences between institutions as well as the territorial inequality in the quality of services provided, as the "ghettoization" of unsuccessful schools occurs (Warrington, 2005; Kovács, 2012).
It is implicit, based on many studies of the issue that small rural IESs are at a disadvantage in comparison to FESs, when it comes to both policies for managing the catchment areas. In the former type of policy, when the school system was managed as a whole unit that is supposed to be as high performing and materially effective as possible, IESs were the most vulnerable during reorganization. As a rule, they were the first to be removed from the system. In the later policy, in which quasi-market mechanisms are introduced into the educational system, FESs are once again more preferred by clients. These schools are often located in the same place where the parents commute to work, or they are found in generally more strategically advantageous locations. Importantly, urban schools also have a persisting image of providing education of higher quality, although this "quality" of education at large schools has never been proven by any data (see Ĺberg-Bengtsson, 2009; Ribchester and Edwards, 1999). We shall keep these conditions in mind during our analyses of model micro-regions in the Czech Republic, where educational policy has also shifted from the first type of management to the second 'quasi-market' type.

\section{Methodology and cartographic visualization}

In order to assess the transformation of the territorial organization of elementary schools and commuting patterns in a given area and time, it is necessary to understand (1) characteristics of the spatial structure of schools, and (2) commuter flows. The chosen model areas were two Czech administrative regions, so-called MEC (municipality with extended competencies) districts: Turnov and Zábřeh (see Fig. 1). The aim of our research was to examine the transformation of school system organization between different eras of educational policy, particularly during the centrally-planned Socialist regime and during the period of transformation after 1989. The availability of relevant data posed the greatest limitations to the research project.

\subsection{School pattern analysis}

To analyze the school patterns, it is important to know the number, type and spatial distribution of schools (whether they are FESs or IESs) in the study area at a certain time. This work utilised a database containing information about the presence of elementary schools at a municipal level in the Czech Republic. This database was compiled by Kučerová (2012) and covers four periods: 1961, 1976, 1990 and 2004. For all municipalities in the case study areas, the number of schools and their types were ascertained at the four mentioned time points. The database was also expanded to include current data from 2011, based on the Database of Statistical Data on Towns and Municipalities.

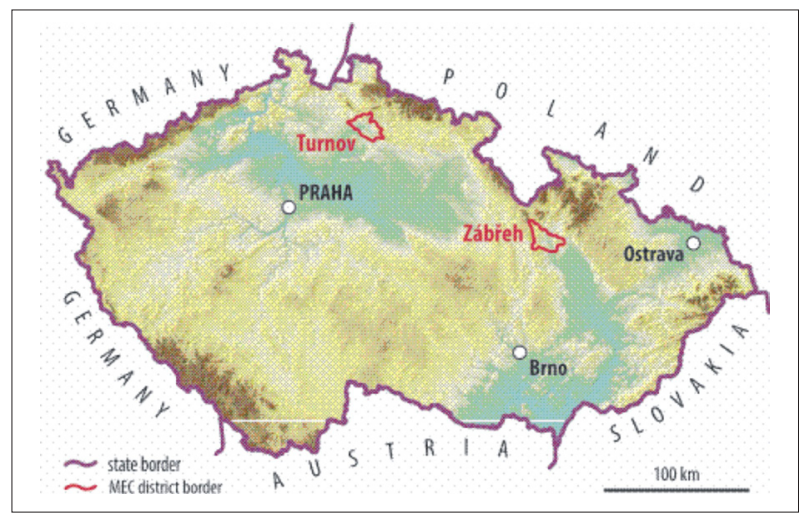

Fig. 1: Location of study area. Source: authors 
Nonetheless, studying the location of schools at the municipal level proved to be insufficient. Particularly at the first studied time point, an elementary school occurred in almost every larger settlement unit, and therefore, there was more than one school in each administrative district of each municipality. Thus, it was necessary to define the exact geographical position of each school precisely. For schools that are still in operation, the address was found either on their webpage or on the webpage of the municipality in which they are located. For schools that were closed during the second half of the $20^{\text {th }}$ century, the information about their location was searched in various types of region-specific documents. Former school buildings were often identified because of their typical architecture. This was done through field research and with the help of applications available on-line (orthophotomaps on the map servers Mapy.cz and Google Maps, and using the Street View application in Google Maps).

\subsection{Commuter flow analysis}

Commuter flows to each school were constructed based on the information about the number of commuters and the directions of their journey. In order to understand commuter patterns and their diversity within a given area daily movements of individuals or groups of individuals were followed from their starting points (their homes, e.g. permanent addresses of commuters) to their destinations (schools). Thus, the number and significance of links between different parts of the study area and the locations of educational institutions were examined. Other authors constructed regional relationships in a similar way, including Hampl, Gardavský, Kühnl (1987), Hampl (2004, 2005), and most recently Mulíček and Kozel (2012). When combined with the information about settlement characteristics in the studied area, an initial view of service provision in the area is obtained. Thus, we can infer some qualitative characteristics of these relationships (e.g. stability, diversity of commuter situations, and competition between schools).

Most of the above-mentioned publications deal with macro-regional and meso-regional commuter patterns. Therefore, for such studies it is sufficient to work with the territorial administrative unit of the municipality. Many studies focusing on the micro-regional level of territorial administrative units, however, (e.g. Dokoupil, 2008), do not deal with relationships between individual settlements. Data about commuting to school are collected once every ten years as part of the population census. Relevant data from the last census (2011) were not available at the necessary territorial detail at the time when this research was conducted. Therefore, older data from the 2001 census were used. The acquisition of these data was commissioned specifically from the Czech Statistical Office, as publicly available statistics publish only commuter flows involving ten or more people. Although the data were used at the municipal scale, in most cases it was possible to determine simple relationships between the commuter flows and the particular schools. The reduction of the school network in the second half of the $20^{\text {th }}$ century was so significant that, with the exception of regional centres (Turnov and Zábřeh), there was not a single municipality in the study areas that would have more than one school in 2001.

It was not possible to acquire comparable data on commuting to schools from before 1989. As the educational policy in that period assigned each pupil to a school that they had to attend based on their domicile, it can be assumed that there were 'no' commuter flows originating from the school catchment area elsewhere. It was not possible, however, to acquire information about the delimitations of school districts in the entire area of both MEC districts. According to personal interviews with employees from regional archives and representatives from local government and schools, there was no single rule in the past for recording how the school districts had been delimited. No cartographic depictions of these districts could be found. Generally, each former municipal office had a list of settlements that belonged to each school. Only a few of these lists have been preserved in the archives. Therefore, data from the 1961 census contained in the Statistical Lexicon of Municipalities of Czechoslovakia 1965, were selected. In its methodology section, it is stated that the publication contains data about the location of elementary schools provided by former local authorities. Crucially, it was found that the data are listed for all municipal parts, since in most areas, there was more than one school in that era. The state of the school network in 1961 also reflects how it had looked before it underwent a massive reduction in later years (Kučerová, 2012).

\subsection{Cartographic visualization of data}

For cartographic visualization, data layers from the ArcČR 5003.0 digital vector geographical database were used, as well as the authors' original layer indicating the locations of schools. Attributes of the existence and types of schools at the two mentioned time points were added to these layers, as well as the proportion of commuting students aged 6-14 from the total number of children of this age outside municipal borders in 2001, and data about where pupils went to FESs and IESs in 1961.

For each studied area, a separate project was created in ArcGIS 10.2. In the first phase, a map scale $(1: 200,000)$ and a map projection were selected (Albers equal area conic map projection using two undistorted parallels and with a cartographic meridian intersecting the depicted area). In ArcGIS, shading was also used to classify the territorial units and schools and for the distribution of composition elements. Then, these layers were exported to Corel DRAW X5 and modified. Figures 2-7 show the resulting maps. Creating the commuter outflow arrows (Fig. 4 and 7) for 2001 was the most time-consuming task. It was necessary to compare the commuting database with the data layer tables. The arrows were manually inserted into the maps to make them illustrative, readable and clear. Based on the number of commuting pupils, arrows of six thicknesses were created for each map. This allowed the comparison of the situation depicted in different maps. Arrows indicating the commuter flows to schools within a MEC district are blue, whereas those indicating flows outside of a MEC district are grey. At the intersection points of the arrows, weaker arrows are interrupted. The same solution is used for places where descriptions intersect arrows. On the map, the percentage of pupils commuting to school from each municipality is expressed using a choroplet map.

\section{School system transformation during the last $\mathbf{5 0}$ years in territorial detail}

\subsection{General trends in the Czech Republic}

Before we turn attention to the rural case study regions, it is necessary to present the main trends in changes happening in the elementary school network in the Czech Republic 
over the last 50 years. The elementary school network in the mid- $20^{\text {th }}$ century can be characterized as very dense with many rural IESs and multi-age classes, even in the smallest settlements (Trnková, Knotová, Chaloupková, 2010). Nevertheless, several factors in the second half of the $20^{\text {th }}$ century were not favourable for maintaining a dense network of elementary schools. Over the course of merely twenty years, the number of elementary schools fell by one half. While there were approximately 8,000 schools in the Czech Republic at the beginning of the 1960s, in the 1980s there were only 4,000 (Kučerová, 2012).

A range of other factors aided these developments. Some are locally specific to the Czech Republic (e.g. the comprehensive policy of planned development for settlements, reforms in the organization of the educational system and schooling). Other factors are of a more general nature (e.g. demographic changes, world-wide trends in teaching concepts, the transformation from an industrial society to the post-industrial one, and related improvements in the effectiveness, speed and accessibility of transportation). Since this massive reduction in the school network several decades ago, the development of the elementary school network has remained stable. There is only a negligible decrease in the number of schools. Each year, the number of school closings has been usually in single digits, although some years have seen several dozen schools cancelled. The decline in the number of schools has also slackened due to a short-term birth rate increase in recent years, which has produced an adequate number of school-aged children (Hulík and Tesárková, 2009).

In the first half of the study period, the Communist regime (1948-1989) determined the educational policy in the Czech Republic. This policy of central planning created a school system that was managed based on directives featuring strictly-defined catchment regions known as "school districts". Each area was assigned a school to which all school-aged children with a permanent address in the area had to attend to complete their compulsory education. Subsequently, during the post-communist period of transformation, the practice of assigning schools was abandoned. The School Act (Act No. 561/2004 Coll.) currently in force uses the term "district school", and every elementary school operated by a municipality must be assigned a certain coverage area for which this school is a district school. But it does not specify that children domiciled in one school district should only attend the elementary school in that district.

District schools are only intended to ensure that pupils can complete compulsory education. Headmasters of district schools are required to prioritize the acceptance of pupils with permanent residence in their school districts. If the maximum occupancy of the school is not met in this way, then any remaining vacancies can be taken by pupils from other regions. Pupils, however, cannot be legally forced to complete their compulsory education in the school, which the municipality of their permanent residence has established for that purpose. Pupils, or their legal guardians, can decide for themselves which elementary school to attend.

Thus, this system is a combination of strictly-defined catchment areas and free market mechanisms. It should be added that most elementary schools in the Czech Republic have been established by non-commercial entities (90\% are run by local governments), and only $2 \%$ of such schools are private (Kučerová, 2012). Therefore, the school system is financed largely from public budgets. Many questions are raised about those schools that are financed by a local government that are attended not only by pupils residing in that particular school's district, but also by students from other localities who attend based on their parents' choice.

\subsection{Spatial relationships in providing elementary education in rural areas}

Both model areas, the Turnov MEC district and the Zábřeh MEC district, cover an area of approximately $250 \mathrm{~km}^{2}$. Turnov and Zábřeh are towns with similar populations (approximately 14,000 inhabitants) and are both microregional centres of rural areas. The number of pupils commuting to schools in Zábřeh was affected by the presence of a nearby town of similar size: Mohelnice. Both Turnov and Zábřeh are located in dales by rivers. Nevertheless, the catchment areas of these regional centres extend into the surrounding highlands with several rural settlements. The most significant difference between the study areas is population density. While Turnov is surrounded by a dense network of very small settlements of less than 100 inhabitants, the population density of the Zábřeh region is much lower and features settlements with more than 200 inhabitants. Already this factor, the size structure of settlements, significantly affects the school pattern.

In 1961, at the beginning of the study period, the number of elementary schools in the two regions was nearly identical: 35 IESs in the Turnov MEC district and 36 in the Zábřeh MEC district, and 7 FESs in each of them. Considering the function of FESs in the school system, it is understandable the number of the schools of this type was less than that of the smaller IESs, which were located in small rural settlements. As a consequence of the fragmented nature of the settlement network in the Turnov region, many settlements in this region did not have their own elementary school in the 1960s. Therefore, many pupils commuted, most often afoot, to schools in the neighbouring villages.

In the following decades, many factors began to contribute to changes in the school patterns. Primary factors included the declining number of pupils in the 1960s, which had a particularly strong impact on rural areas, and the contemporary policies. These policies attempted to concentrate most functions and investments into selected centres with large populations by creating "a centrebased system of settlement". School reforms in the 1960s and 1970s had a non-negligible impact. New educational concepts recommended the closure of IESs, especially small schools with mixed classes (Trnková, 2006). The transport infrastructure in rural areas slowly began to improve with regular bus services (Kučerová, Mattern, Štych, Kučera, 2011) that allowed pupils to travel greater distances to schools. As a result of all these factors, a massive and yet-to-be repeated reduction in IESs took place across the Czech Republic, which deepened the unequal distribution of schools that began to appear in the second half of the 1960s and all through the 1970s (Kučerová, 2012).

Although the school pattern changes in both study areas corresponded with the above-described countrywide trends, the intensity and course of these changes slightly differed in some aspects. While only six schools were closed in the Turnov region before 1976, only 23 of the original 36 schools remained in the Zábřeh region in 1976. The school network in the Zábřeh MEC then stabilized with approximately 20 IESs and 7 FESs. Turnov experienced a period of radical school closures in the second half of the 1970s. The number 
of schools was reduced by more than one half. While there were 29 IESs in 1976, only 12 were recorded at the following point in time (1990). In 2011, there still were seven FESs. The number of IESs in the Zábřeh region increased by seven and numbered 18, as compared to 11 in the Turnov region. Thus, the current number of schools in the Zábřeh MEC district amounts to approximately one half of that recorded in the 1960s, while in the Turnov region there is only one third of the number of schools.

These changes significantly influence commuter relationships, which are depicted in Figs. 2-7. Figures 2, 3, 5 and 6 depict the state of school catchment districts in the Turnov and Zábřeh regions in 1961: Figures 2 and 5 depict the settlements falling in the catchment areas of IESs in 1961, and Figures 3 and 6 depict the settlements falling into the catchment areas of FESs. Both areas are highly fragmented in terms of the assignment to IESs in the 1960s. Every IES provides services in a small catchment area in which the distance to the nearest school rarely exceeds $3 \mathrm{~km}$ in a beeline. In the Zábřeh region, the catchment districts mainly cover the area of just one settlement, whereas in the Turnov region, pupils from multiple settlement units attended one IES. This was influenced by the already-mentioned differences in the settlement patterns of these case study areas.

As far as the FES catchment areas are concerned, most of the area studied is covered by district schools that are located in regional centres, i.e. in Turnov and Zábřeh. The Turnov school district, however, is much larger than the Zábřeh school district. The reason for this is not only that in 1961 there were three FESs in Turnov and only two in Zábřeh, but also that Turnov had always served as a stronger micro-regional centre to which bus routes led from various directions, which made it possible for pupils even from the periphery to commute directly to school by bus without having to change. The broadly-defined borderlands of both regions include a ring of areas falling in the catchment areas of FESs in smaller micro-regional centres. These were the largest villages in the micro-region with populations of up to 1,000. Zábřeh has more such potential "competitors". It can be observed that the Turnov region, as opposed to Zábřeh, is a more compact, easy-to-define unit that is held together by a dominant and important centre. For school pattern variability, this type of pattern is not beneficial, as IESs face strong competition from easily accessible "opponents": FESs located in the town.

Thus, the dominant position of Turnov had a stronger impact on school closings in the 1960s and 1970s. Figures 4 and 7 depict commuter flows in 2001. It is clear from the depictions that even early elementary education in the catchment areas of former IESs is now covered by FESs in Turnov: see, for example, the municipalities of Klokočí and Mírová pod Kozákovem to the east of Turnov, or the coverage of the municipality of Pěnčín, split between Kobyly and Turnov.) The commuter outflow from oscillating regions in the Zábřeh area was often directed towards the closest small FES in local centres: see the commuter flow from Jedlí to Štíty, not to the actual centre of the region, Zábřeh. Commuter flow directions for pupils completing upper elementary school outside of municipalities that have maintained an IES, generally respect the catchment districts of the FESs to which these municipalities had been assigned in the past. The statistical data about the commuter inflow and outflow do not make it possible to determine how many lower elementary school pupils from municipalities with IESs attend FESs outside of their municipality. This information can be acquired only by directly asking the inhabitants of such municipalities or school officials.

\section{Conclusions}

In accordance with Tricker and Mills (1987), cited in the Introduction, and based on the two case studies of rural Czech micro-regions (i.e. MEC Turnov district and MEC

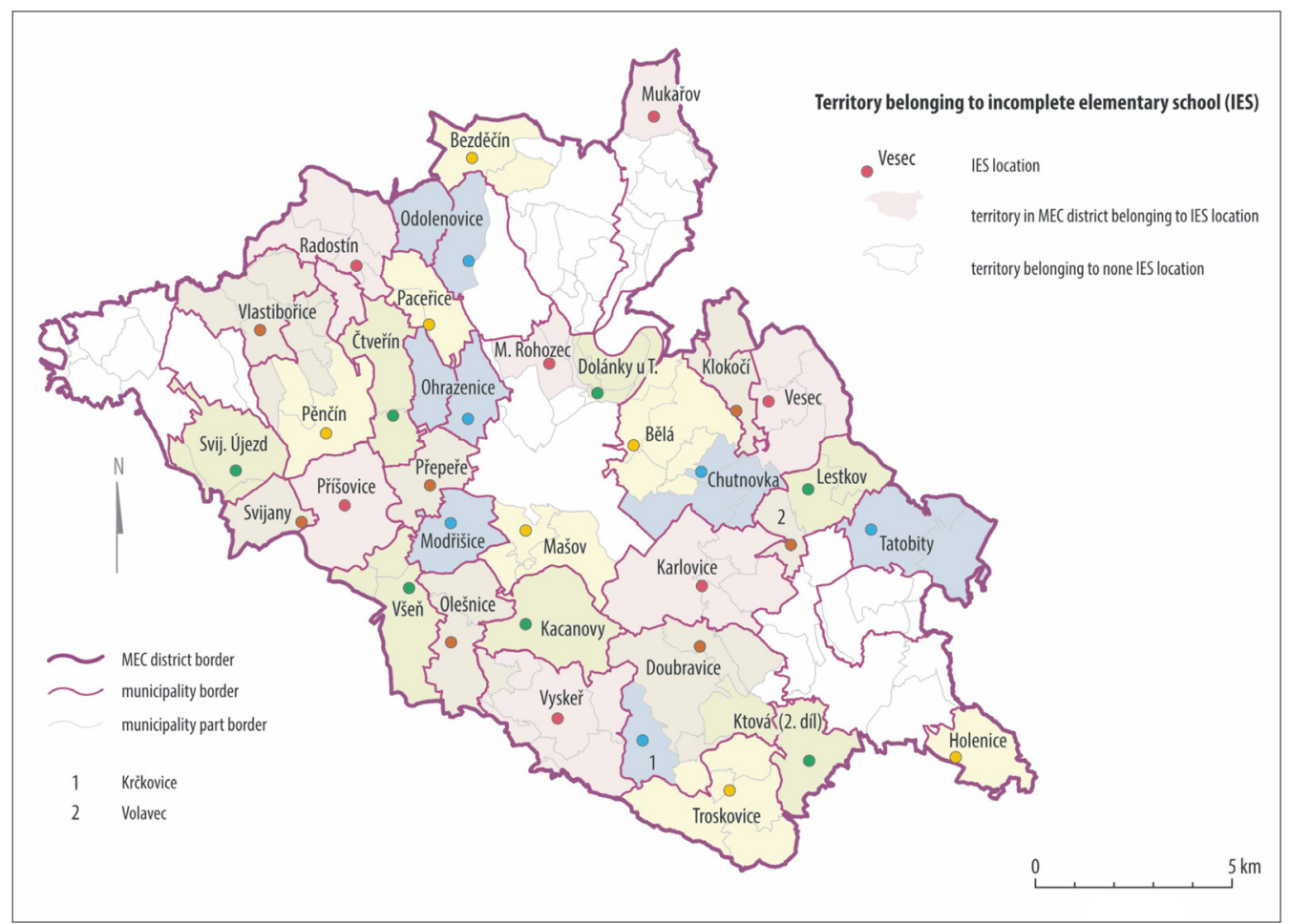

Fig. 2: Catchment areas of incomplete elementary schools (IES) in 1961, Turnov MEC district Source: authors, based on the Statistical Lexicon of Municipalities of Czechoslovakia 1965 
Zábřeh district), we can confirm that this 50-year time period saw: (1) a massive reduction in small rural schools; and (2) strengthening of the functional significance of large settlements (towns).

In both of the model micro-regions, direct commuter links to the regional centres, as well as partially to other larger settlements in these areas, have strengthened. Most rural settlements have lost their educational functions, and have become fully dependent on towns at higher levels of the settlement hierarchy.

The school system is more concentrated in the MEC Turnov district than in the Zábřeh region, mainly because of its fragmented settlement pattern. The distance for commuting to school, even by younger pupils, is greater

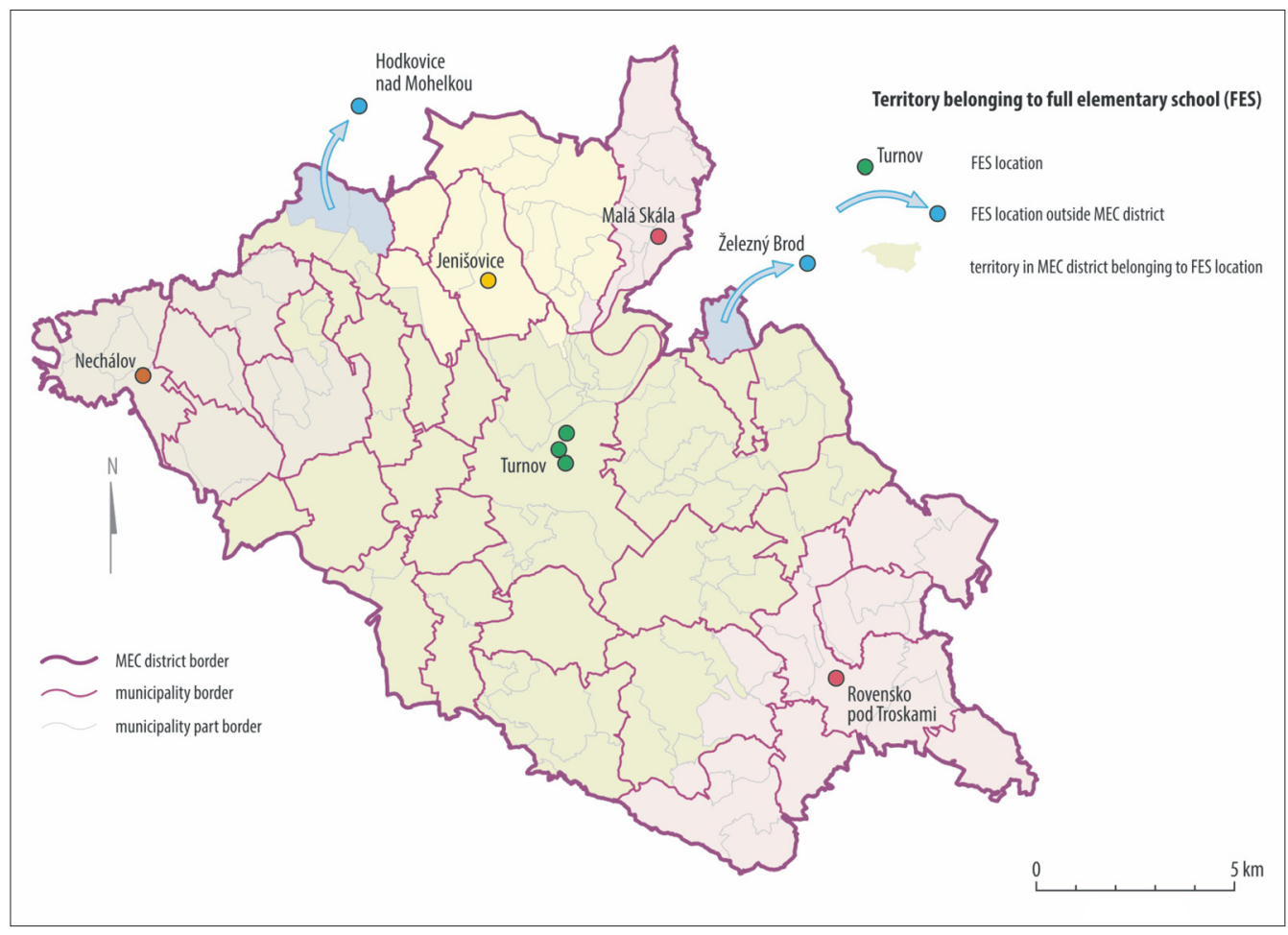

Fig. 3: Catchment areas of full elementary schools (FES) in 1961, Turnov MEC district Source: authors, based on the Statistical Lexicon of Municipalities of Czechoslovakia 1965

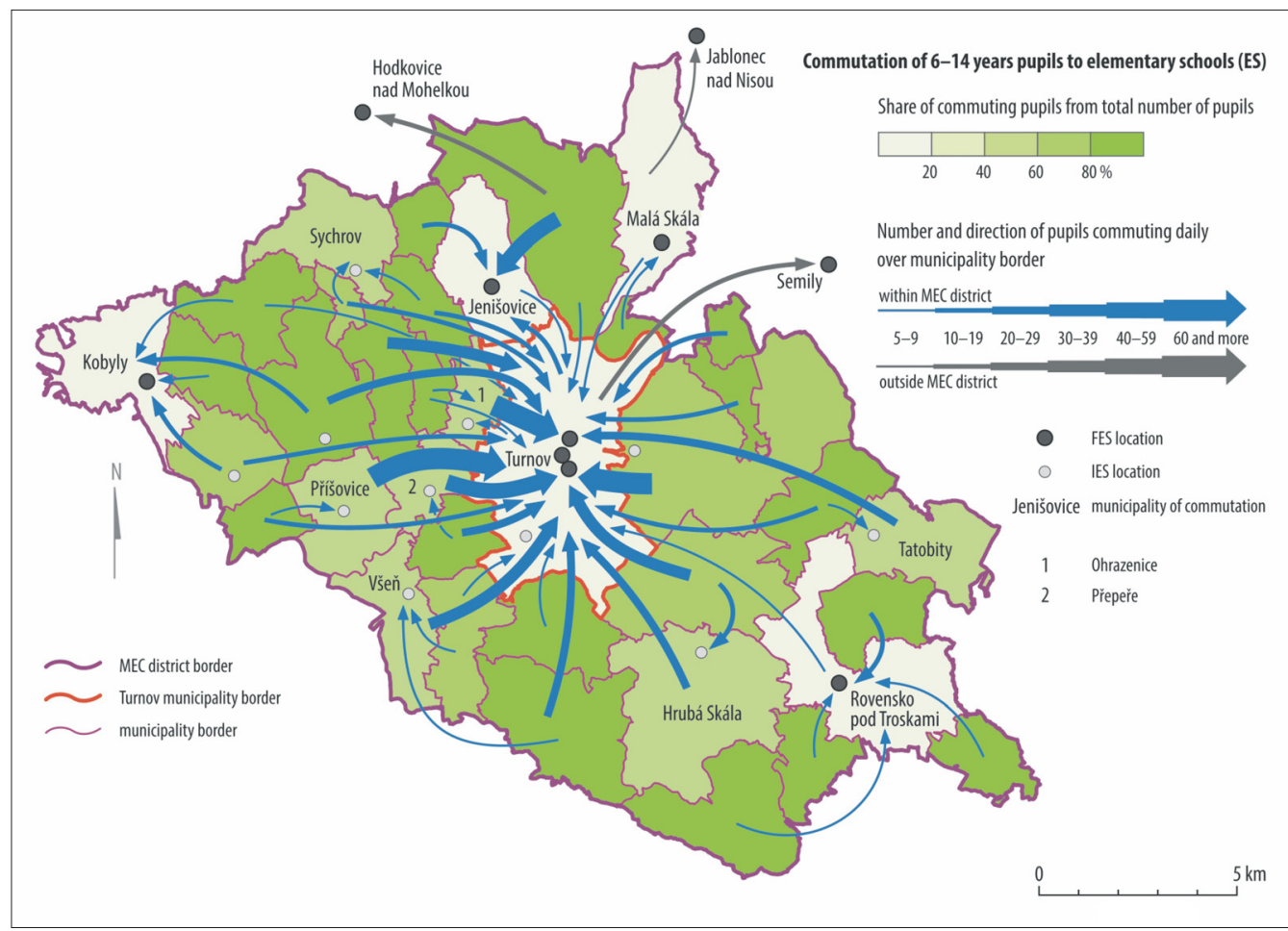

Fig. 4: The number of pupils commuting daily to elementary schools outside of their places of permanent residence and commuter flow directions in 2001, Turnov MEC district

Sources: authors, based on data from the Czech Statistical Office 
and the children enter environments different from their place of residence. In addition, the settlement pattern character of the Turnov region affects its overall transport accessibility. In such areas, it is always more difficult to operate mass public transit that is accessible to all and that has connections suitable for getting to and leaving school on time. Therefore, it could be assumed that when selecting schools, many parents in the Turnov MEC district will consider how they can combine their children's commute with their own spatial and temporal movement within their region, which often involves travelling to the micro-regional centre (Temelová, Novák, Pospíšilová, Dvořáková, 2011; Chromý, Jančák, Marada, Havlíček, 2011). This may result in parents choosing a school in the centre, and

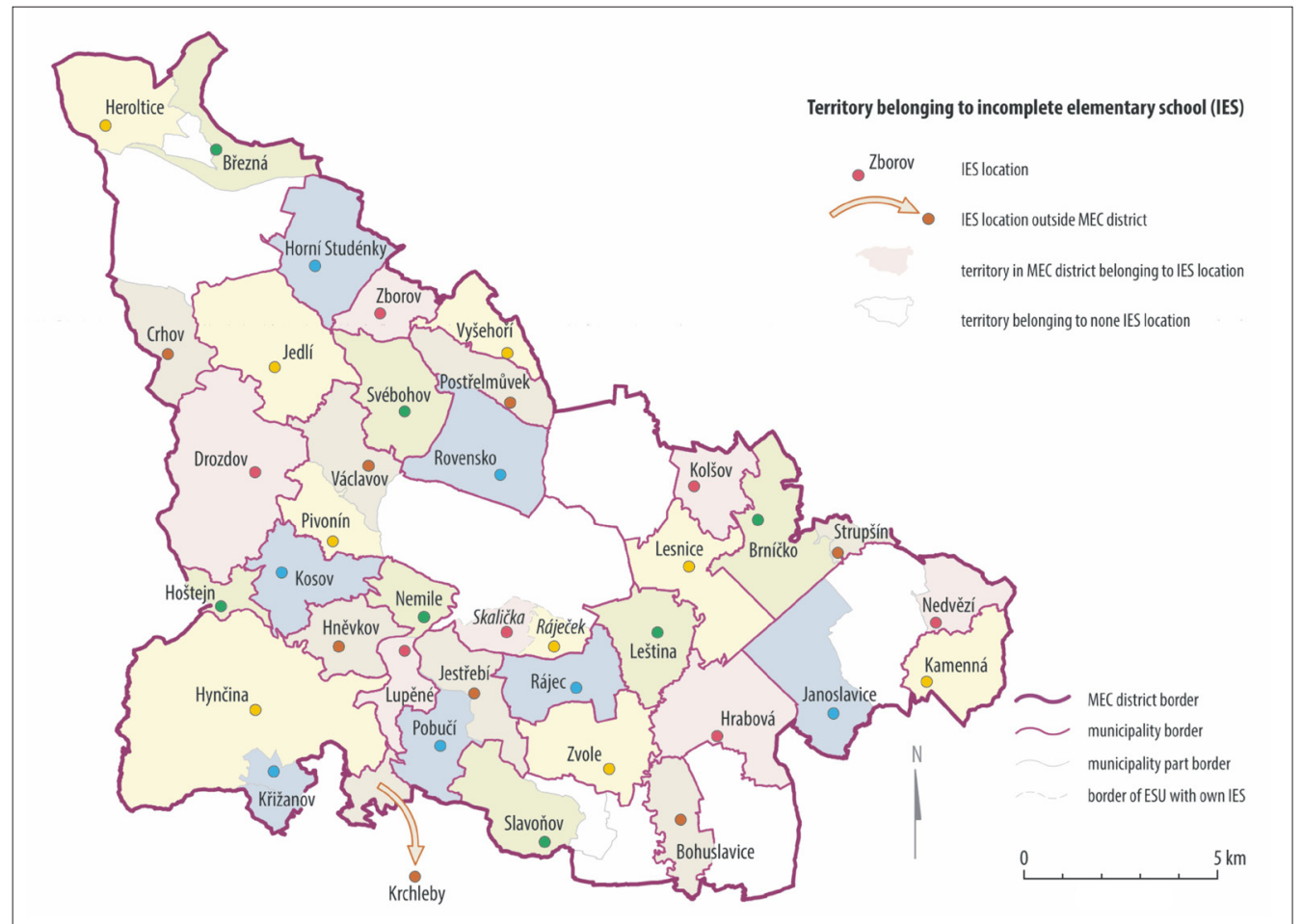

Fig. 5: Catchment areas of incomplete elementary schools (IES) in 1961, Zábřeh MEC district (note: ESU = Elementary settlement unit (a type of territorial statistical unit)

Source: authors, based on the Statistical Lexicon of Municipalities of Czechoslovakia 1965

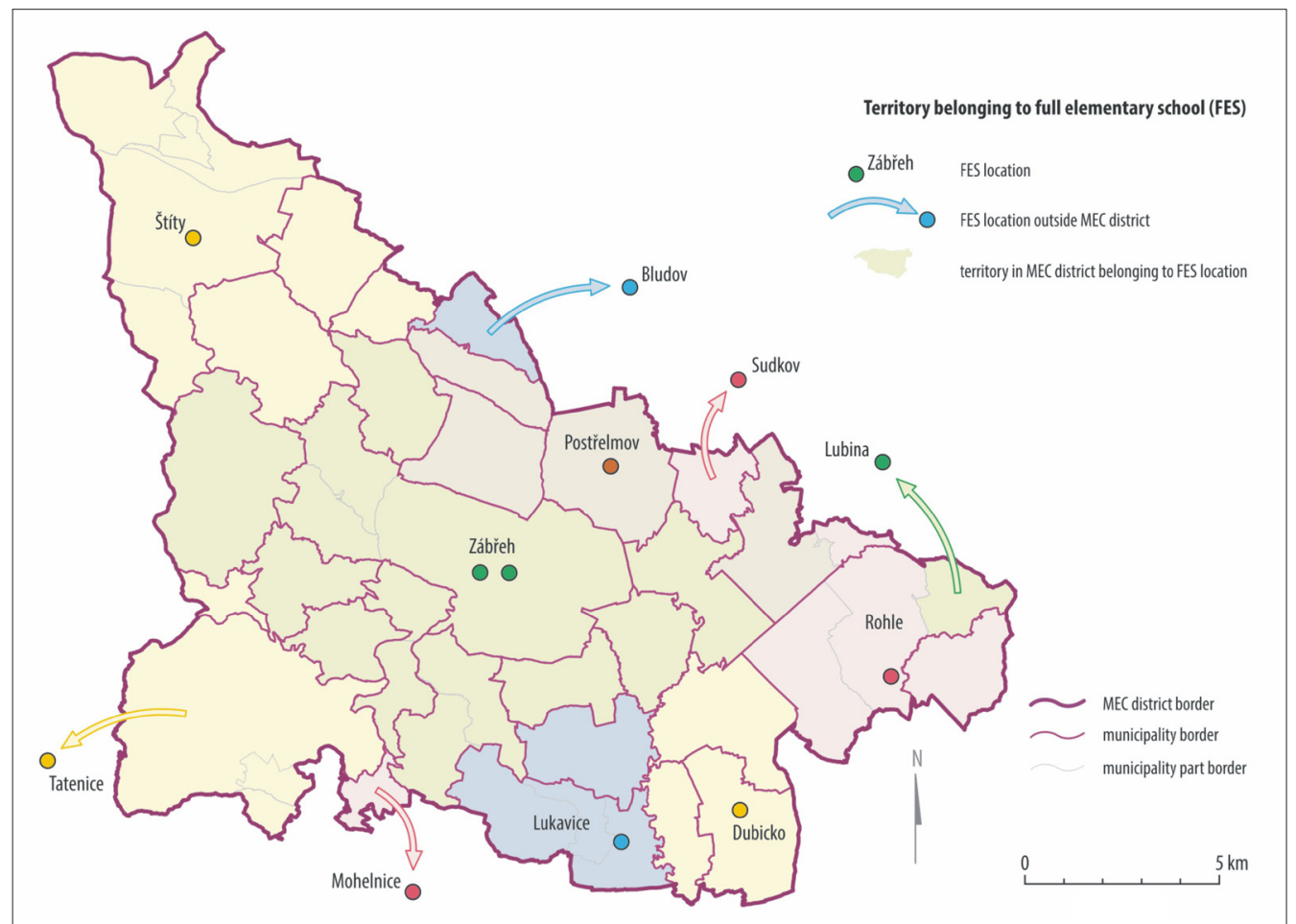

Fig. 6: Catchment areas of full elementary schools (FES) in 1961, Zábřeh MEC district Source: authors, based on the Statistical Lexicon of Municipalities of Czechoslovakia 1965 


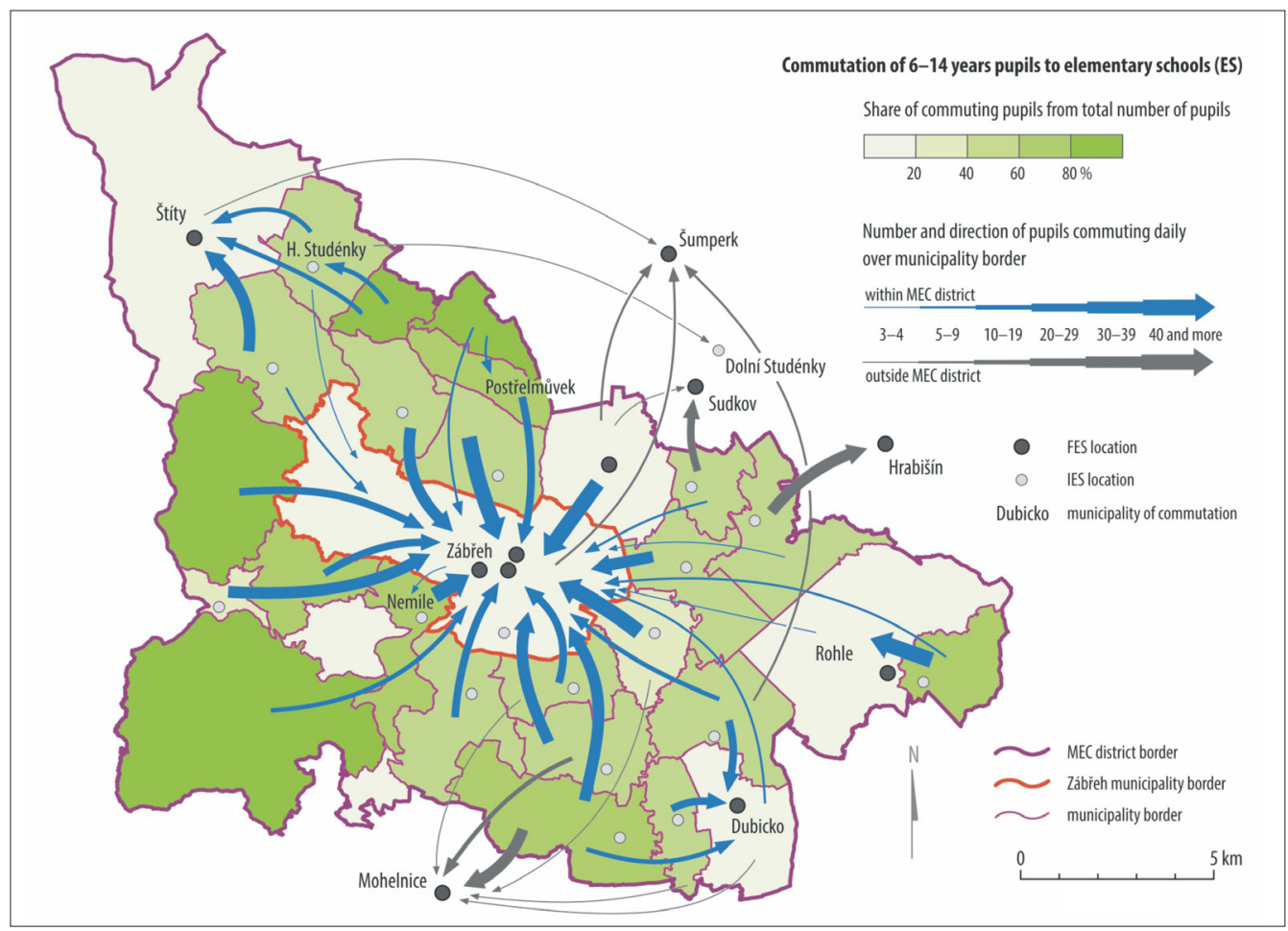

Fig. 7: The number of pupils commuting daily to elementary schools outside of their places of permanent residence and commuter flow directions in 2001, Zábřeh MEC district Sources: Authors, based on data from the Czech Statistical Office

thus regional links to the centre are strengthened. This is, however, still just an unsubstantiated hypothesis that must be confirmed.

The policies of the Communist regime in the Czech Republic accelerated and reinforced both identified processes of reduction and concentration. In particular, those policy measures geared towards governing the settlement system and distributing investments were significant, and of course the concept of educational policy. The object of interest for educational policy was the school pattern, which was considered an egalitarian unit. This concept of educational policy corresponded with the approaches taken to the educational system in most countries (including western ones). The system was guaranteed to ensure an educated labour force for the economy. In Communist Czechoslovakia, it was also supposed to produce citizens loyal to the state. In order to sustain the elementary school system with a lack of pupils in rural peripheral settlements, a conscious, planned and state-directed liquidation of a large number of IESs was launched (Trnková, Knotová, Chaloupková, 2010). Over the course of twenty years, one half of the schools were closed in one of our study micro-regions and the other area witnessed a two-thirds decrease in the number of schools. As a result, school commuting distances multiplied.

The introduction of a market economy after the fall of the Communist regime in 1989 also introduced elements of competition into a new educational policy. Local government functions have been returned to the municipalities, so that they can once again make decisions about what happens in their territory. Municipalities thus became, among other things, responsible for running elementary schools. Even though a vast majority of the monies needed for the operation of schools comes from the state in the form of redistributed tax revenues, local governments can support their schools by providing additional funds from the municipal budget necessary for operating "less effective schools". Therefore, municipalities are free to decide whether they will finance a school in their jurisdiction, even a school with a small number of students. The fact that there are schools that have been preserved in the case study areas (particularly IESs) can be viewed as an expression of each municipality's support for its school, and the municipality's attempts at maintaining that school.

Another consequence of the free market has an antagonistic effect: parental choice. The increasingly strong links between rural municipalities and micro-regional centres do not just result from the reduction of IESs that took place before 1989 . They are also largely the result of parents' preferences in selecting the most suitable elementary school for their children today. These schools can be preferred due to their easy accessibility or due to their better image. Commuter flows from smaller municipalities (Figs. 4 and 7) that have their own elementary school may be evidence of this. In the future, could this approach to educational policy lead to more extensive IES closures, as reported, for example, by Bell and Sigsworth (1987)?

These questions lead to further research. One question that requires more research is: how have the changes in the school patterns, discussed above, been reflected in the relations between the schools in the region? On the one hand, this question particularly applies to relations between IESs in rural areas, but also to relations between rural IESs and the larger FESs in towns, on the other hand. The situation in the Zábřeh MEC district, where a larger number of IESs remained in operation, may put these schools in the position of strong competitors. They are dependent upon local demand, especially as birth rates and the number of pupils decline (Hulík and Tesárková, 2009). In contrast, IESs in the Turnov region may come up against more competition with urban FESs in the micro-regional centre. The relatively large distances between the small numbers of IESs in the Turnov MEC district, perhaps, 
does not necessarily lead to an overlap in catchment areas. Therefore, a "common enemy" in the form of FESs could act as a bonding agent among these IESs. It could result in the formation of a counter-weight to the strong FES competitors, and to searching for joint development and cooperative strategies. To answer this type of question, however, more purely qualitative research is required.

\section{Acknowledgement}

The paper is based on the results of a research project supported by the Czech Science Foundation, project GA CR No. P404/12/P374. The authors thank the Foundation for this support.

\section{References:}

ÅBERG-BENGTSSON, L. (2009): The Smaller the Better? A Review of Research on Small Rural Schools in Sweden. International Journal of Educational Research, 48: 100-108.

Act No. 561/2004 Coll., the School Act, from 24 Sept. 2004.

Arc ̌́R 500. Digital Vector Geographic Database of the Czech Republic. [online] [cit. 05.03.2014]. Available at: http:// www.arcdata.cz/produkty-a-sluzby/geograficka-data/ arcer-500/

BAJERSKI, A. (2011): Organizacja przestrzenn i funkcjonowanie usług edukacyjnych w aglomeracji poznańskiej. Poznań, Bogucki Wydawnictwo Naukowe.

BASU, R. (2007): Negotiating Acts of Citizenship in an Era of Neoliberal Reform: The Game of School Closures. International Journal of Urban and Regional Research, 31: 109-127.

BELL, A., SIGSWORTH, A. (1987): The Small Rural Primary School: A Matter of Quality. London, Routledge.

BRADFORD, M. (1991): School-performance Indicators, the Local Residential Environment, and Parental Choice. Environment and Planning A, 23: 319-332.

BROWN, P., HALSEY, A. H., LAUDER, H., WELLS, A. S. (1997): The transformation of education and society: An introduction. In: Halsey, A. H., Lauder, H., Brown, P., Wells, A. S. [eds.]: Education. Culture, Economy, and Society (p. 1-44) Oxford, Oxford University Press.

Database of Statistical Data on Towns and Municipalities. Czech Statistical Office, 2004, 2005 and 2011 [online] [cit. 13.10.2013]. Available at: http://www.czso.cz/lexikon/mos

DOKOUPIL, A. (2008): Spádovost za službami ve vybraném mikroregionu. Diploma thesis. Brno, Masarykova univerzita, Ekonomicko-správní fakulta.

DOWLING, J. (2009): Changes and challenges: Key issues for Scottish rural schools and communities. International Journal of Educational Research, 48: 129-139.

DVOŘÁK, D., STARÝ, K., URBÁNEK, P., CHVÁL, M., WALTEROVÁ, E. (2010): Česká základní škola: Vícepř́padová studie. Praha, Karolinum.

Google Maps. [online] [cit. 01.12.2013]. Available at: http:/ maps.google.com

HAMPL, M. (1998): Realita, společnost a geografická organizace: hledání integrálního řádu. Praha, Karolinum.

HAMPL, M. (2004): Současný vývoj geografické organizace a změny v dojížd'ce za prací a do škol v Česku. Geografie, 109(3): 205-222.
HAMPL, M. (2005): Geografická organizace společnosti v České republice: transformační procesy a jejich obecný kontext. Praha, Univerzita Karlova v Praze, Př́rodovědecká fakulta, katedra sociální geografie a regionálního rozvoje.

HAMPL, M., GARDAVSKÝ, V., KÜHNL, K. (1987): Regionální struktura a vývoj systému osídlení ČSR. Praha, Univerzita Karlova v Praze.

HULÍK, V., TESÁRKOVÁ, K. (2009): Dopady demografického vývoje na vzdělávací soustavu v České republice. Orbis Scholae, 3(3): 7-23.

CHROMÝ, P., JANČÁK, V., MARADA, M., HAVLÍČEK, T. (2011): Venkov - žitý prostor: regionální diferenciace percepce venkova představiteli venkovských obcí v Česku. Geografie, 116(1): 23-45.

KALAOJA, E., PIETARINEN, J. (2009): Small rural primary schools in Finland: A pedagogically valuable part of the school network. International Journal of Educational Research, 48: 109-116.

KARLBERG-GRANLUND, G. (2009): Att förstĺ det stora i det lilla. Byskolan som pedagogik, kultur och struktur (Understanding the great in the small. Pedagogy, culture and structure of the village school). Dissertation. Vaasa, Pedagogiska fakulteten, Ĺbo Akademi in Vasa.

KEARNS, R., LEWIS, N., McCREANOR, T., WITTEN, K. (2009): 'The Status Quo Is Not an Option': Community Impacts of School Closure in South Taranaki, New Zealand. Journal of Rural Studies, 25: 131-140.

KOVÁCS, K. (2012): Rescuing a Small Village School in the Context of Rural Change in Hungary. Journal of Rural Studies, 28: 108-117.

KRAFT, S. (2012): Dopravní klasifikace středisek osídlení České republiky: Využití metod shlukové analýzy. Moravian Geographical Reports, 20(3): 38-49.

KUČEROVÁ, S. (2012): Proměny územní struktury základního školství v Česku. Praha, ČGS.

KUČEROVÁ, S., KUČERA, Z. (2012): Changes in the Spatial Distribution of Elementary Schools and Their Impact on Rural Communities in Czechia in the Second Half of the $20^{\text {th }}$ Century. Journal of Research in Rural Education, 27: 1-17.

KUČEROVÁ, S., MATTERN, T., ŠTYCH, P., KUČERA, Z. (2011): Změny dostupnosti základních škol v Česku jako faktor znevýhodnění regionů a lokalit. Geografie, 116(3): 300-316.

KVALSUND, R. (2009): Centralized Decentralization or Decentralized Centralization? A Review of Newer Norwegian Research on Schools and Their Communities. International Journal of Educational Research, 48: 89-99.

Mapy.cz [online] [cit. 01.12.2013]. Available at: http://www. mapy.cz

MARSDEN, W. E. (1977): Historical Geography and the History of Education. History of Education, 6(1): 21-42.

MARYÁŠ, J. (1983): K metodám výběru středisek maloobchodu a sfér jejich vlivu. Zprávy Geografického ústavu ČSAV, 20(3): 61-77.

MULÍČEK, O., KOZEL, J. (2012): Metodika vymezení vztahově uzavřených funkčních regionů. Brno, Polyreg. 
NEKORJAK, M., SOURALOVÁ, A., VOMASTKOVÁ, K. (2011): Uvíznutí v marginalitě: vzdělávací trh, „romské školy“ a reprodukce sociálně prostorových nerovností. Sociologický časopis, 47(4): 657-680.

NITTA, K. A., HOLLEY, M. J., WROBEL， S. L. (2010): A Phenomenological Study of Právní výklady (Law construction) 1/2005, Č.j. 20 556/2005-14, MŠMT.

Rural School Consolidation. Journal of Research in Rural Education, 25(2): 1-19.

RIBCHESTER, C., EDWARDS, B. (1999): The Centre and the Local: Policy and Practice in Rural Education Provision. Journal of Rural Studies, 15(1): 49-63.

TEMELOVÁ, J., JAKUB N., POSPÍŠILOVÁ, L, DVOŘÁKOVÁ, N. (2011): Každodenní život, denní mobilita a adaptační strategie obyvatel $\mathrm{v}$ periferních lokalitách. Sociologický časopis, 47(4): 831-858.

TRICKER, M., MILLS, L. (1987): Education services. In: Cloke, P. [ed.]: Rural Planning: Policy into Action? (pp. 37-55). London, Harper and Row.

TRNKOVÁ, K. (2006): Vývoj malotřídních škol v druhé polovině 20. století. Sborník prací FF Masarykovy univerzity, U 11 (pp. 133-144), Brno.
TRNKOVÁ, K., KNOTOVÁ, D., CHALOUPKOVÁ, L. (2010): Malotřídní školy v České republice. Brno, Paido.

Ústřední komise lidové kontroly a statistiky a ministerstvo vnitra (1966): Statistický lexikon obcí ČSSR 1965. Praha.

VÁŇOVÁ, R. (2007): Školský systém v českých zemích vývoj a současný stav. In: Vališová, A., Kasíková, H. et al.: Pedagogika pro učitele (pp. 69-90). Praha, Grada.

WALKER, M., CLARK, G. (2010): Parental choice and the rural primary school: Lifestyle, locality and loyalty. Journal of Rural Studies, 26: 214-249.

WARRINGTON, M. (2005): Mirage in the Desert? Access to Educational Opportunities in an Area of Social Exclusion. Antipode, 37(4): 796-816.

WHITE, S., CORBETT, M. (2014): Doing Educational Research in Rural Settings: Methodological issues, international perspectives and practical solutions. London and New York, Routledge.

WITTEN, K., McCREANOR, T., KEARNS, R., RAMASUBRAMANIAN, L. (2001): The Impacts of a School Closure on Neighbourhood Social Cohesion: Narratives from Invercargill, New Zealand. Health \& Place, 7: 307-317.

Initial submission 16 May 2014, final acceptance 3 November 2014

Please cite this article as:

KUČEROVÁ, S. R., BLÁHA, J. D., KUČERA, Z. (2015): Transformations of Spatial Relationships in Elementary Education: A Case Study of Changes in Two Czech Rural Areas since the Second Half of the 20 ${ }^{\text {th }}$ century. Moravian Geographical Reports, 23(1): 34-44. DOI: 10.1515/ mgr-2015-0004. 